\title{
FROM RESIDENCY
}

\section{TO RETIREMENT}




\section{Critical Issues in Health and Medicine}

EDITED BY RIMA D. APPLE, UNIVERSITY OF WISCONSIN-MADISON, AND JANET GOLDEN, RUTGERS UNIVERSITY-CAMDEN

Growing criticism of the U.S. health care system is coming from consumers, politicians, the media, activists, and health care professionals. Critical Issues in Health and Medicine is a collection of books that explores these contemporary dilemmas from a variety of perspectives, among them political, legal, historical, sociological, and comparative, and with attention to crucial dimensions such as race, gender, ethnicity, sexuality, and culture.

For a list of titles in the series, see the last page of the book. 


\section{FROM RESIDENCY TO RETIREMENT}

Physicians' Careers over

a Professional Lifetime

T ER R Y M Z R A H I

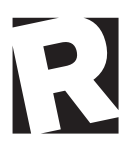

RU TGERS UNIVERSITY PRESS

New Brunswick, Camden, and Newark, New Jersey, and London 
Library of Congress Cataloging-in-Publication Data

Names: Mizrahi, Terry, author.

Title: From residency to retirement: physicians' careers over a professional lifetime /

Terry Mizrahi.

Description: New Brunswick: Rutgers University Press, [202I] | Series: Critical issues

in health and medicine Includes bibliographical references and index.

Identifiers: LCCN 2020031I06 | ISBN 9780813570020 (cloth) | ISBN 9780813570044 (pdf) |

ISBN 97808I359I322 (epub) | ISBN 9781978822764 (mobi)

Subjects: LCSH: Physicians-Anecdotes. | Physician and patient-Anecdotes. |

Residents (Medicine)—Job satisfaction. | Residents (Medicine)—Job stress.

Classification: LCC R705.M59 202I | DDC 610.92 [B]—dc23

LC record available at https://lccn.loc.gov/2020031106

A British Cataloging-in-Publication record for this book is available from the British Library.

Copyright (C) 202I by Terry Mizrahi

All rights reserved

No part of this book may be reproduced or utilized in any form or by any means, electronic or mechanical, or by any information storage and retrieval system, without written permission from the publisher. Please contact Rutgers University Press, ro6 Somerset Street, New Brunswick, NJ 0890I. The only exception to this prohibition is "fair use" as defined by U.S. copyright law.

$\ominus$ The paper used in this publication meets the requirements of the American National Standard for Information Sciences-Permanence of Paper for Printed Library Materials, ANSI Z39.48-1992.

www.rutgersuniversitypress.org

Manufactured in the United States of America 
To my inspiring grandchildren Zachary, Benjamin, and Anna-I wish you a life as dedicated and purposeful as that of the doctors in these pages. 
